\title{
HUBUNGAN STRESS PSIKOSOSIAL DENGAN STATUS GIZI PADA MAHASISWA KESEHATAN DI KABUPATEN JEMBER
}

\author{
Mad Zaini \\ Fakultas Ilmu Kesehatan Universitas Muhammadiyah Jember \\ Korespondensi penulis, e-mail: madzaini18@gmail.com
}

\begin{abstract}
ABSTRAK
Stres merupakan respon tubuh tidak spesifik terhadap kebutuhan tubuh yang terganggu. Status nutrisi dapat diukur dari indeks massa tubuh. Kondisi psikologis sseeorang seringkali menyebabkan individu cenderung melakukan mekanisme coping mechanism. Penelitian ini merupakan penelitian analitik observasional dengan pendekatan cross sectional. Subjek penelitian berjumlah 92 responden. Penelitian dilakukan di Institusi Pendidikan Tinggi Kesehatan di Kabupaten Jember. Berdasarkan analisis statistik diperoleh nilai signifikansi (p) yang didapatkan adalah 0,458 (p>0,05) yang artinya tidak ada hubungan yang bermakna antara tingkat stres psikososial dengan status gizi pada mahasiswa. Perubahan nutrisi pada kondisi stress dapat terjadi melalui adanya gangguan makan atau gangguan penyerapan gizi dalam tubuh. Kondisi psikologis seorang mahasiswa yang penuh stress akan menyebabkan individu cenderung melakukan mekanisme koping. Mekanisme koping dapat berupa positif dan negatif. Peneliti berpendapat bahwa stress psikososial tidak secara langsung berpengaruh pada status nutrisi, melainkan pada pola perilaku dalam pemenuhan nutrisi atau pola makan. Selain itu dampak stress psikososial akan dapat dinilai apabila kondisi stress berlangsung lama atau bersifat kronis.
\end{abstract}

Kata kunci : stress psikososial, status nutrisi

\section{PENDAHULUAN}

Usia remaja menjadi periode yang mendukung terhadap perubahan fisik, psikologis, sosial. Pada tahap ini, remaja seringkali mengalami kesulitan terutama dalam menghadapi perubahanperubahan fisik, psikologis, dan sosialnya. Kesulitan dalam beradaptasi dengan perubahan-perubahan tersebut menjadi stressor dan mengakibatkan remaja berada pada kondisi rentang stress (Sarwono, 2010). Respon dan tingkat stress diketahui mempunyai dampak terhadap status nutrisi. Gejala gangguan nutrisi yang muncul sebagai akibat dari adanya perubahanperubahan fisik, psikologis dan sosial bervariasi mulai dari perubahan nafsu makan sampai dengan munculnya gangguan pola makan seperti anoreksia nervosa dan bulimia nervosa.

Hasil Riset Kesehatan Dasar tahun 2013 menunjukkan bahwa prevalensi gangguan mental emosial yang ditunjukkan dengan gejala kecemasan dan depresi untuk usia 15 tahun sekitar 14 juta orang atau $6 \%$ dari jumlah penduduk Indonesia. Sedangkan berkaitan dengan masalah gizi remaja, sekitar $12 \%$ remaja laki-laki dan 23\% remaja perempuan mengalami anemia, yang sebagian besar disebabkan oleh pola makan dan asupan nutrisi yang

Jurnal Kesehatan, vol. 8, 2019, ISSN: 2301-783X Akademi Keperawatan Ngesti Waluyo 
tidak adekuat (Depkes, 2018). Masalah gizi pada remaja akan berdampak serius terhadap penurunan imunitas, konsentrasi, prestasi belajar, kebugaran serta produktifitas remaja. Selain stress psikososial, masih banyak lagi masalah yang dihadapi oleh remaja dan berdampak negatif terhadap kesehatan dan status gizi remaja.

Penelitian yang dilakukan Mutiara Tirta dan Ronny Tri W tahun 2010 menunjukkan bahwa kecukupan asuhan gizi sejalan dengan peningkatan kondisi stress yang dialami oleh seseorang. Selama dalam kondisi stress, terjadi perubahan pola makan berupa penurunan atau peningkatan nafsu makan. Remaja dalam kondisi tertekan cenderung melakukan mekanisme koping dengan cara memperbanyak makan yang terbukti efektif menimbulkan rasa nyaman. Kondisi stress yang dialami remaja akan memicu kelenjar adrenal melepaskan kortisol lebih banyak sebagai respon alami tubuh terhadap kondisi stress. Tingginya kadar kortisol akan merangsang tubuh mengeluarkan hormone insulin, leptin dan sistem neuropeptide yang akan membuat otak membangkitkan rasa lapar sehingga timbul keinginan untuk makan, memilih makanan yang tinggi gula dan lemak serta berkalori (Andriani. M, dkk, 2012). Kondisi tersebut pada akhirnya mempengaruhi status nutrisi remaja.

Kondisi yang menjadi stressor dapat juga dialami oleh mahasiswa kesehatan, terutama mahasiswa tingkat pertama. Stressor yang muncul dapat berupa perubahan lingkungan belajar, lingkungan pertemanan serta tempat tinggal yang baru (tempat kos). Perubahan-perubahan yang dialami tersebut menuntut mahasiswa untuk melakukan adaptasi. Kesulitan dalam beradaptasi mendorong mahasiswa untuk melakukan mekanisme koping seperti perubahan pola makan. Berdasarkan uraian tersebut, peneliti tertarik untuk mengetahui hubungan stress psikososial dengan status nutrisi mahasiswa Kesehatan di Kabupaten Jember.

\section{BAHAN DAN METODE}

Penelitian ini merupakan penelitian cross sectional, yaitu untuk mengetahui bagaimana hubungan stress psikososial dengan status gizi pada mahasiswa kesehatan di Kabupaten Jember. Penelitian ini merupakan penelitian non eksperimental dimana dalam penelitian ini tidak dilakukan manipulasi variabel (K.K Dharma, 2011). Pengumpulan data penelitian dilakukan dengan menggunakan kuesioner. Sebanyak 92 responden. Pengambilan sample dilakukan secara total sampling.

\section{HASIL PENELITIAN}

Karakteristik responden dikelompokkan berdasarkan jenis kelamin, usia, stress psikososial dan status nutrisi. Pada penelitian ini sebagian besar adalah responden berjenis kelamin perempuan yaitu sebanyak 64 responden. Berdasarkan tingkat usia, sebagian besar responden adalah berusia 19-21 tahun yaitu sebanyak 89 responden. Sedangkan tingkat stress psikososial sebagian besar responden berada pada kondisi normal yaitu sebanyak 59 responden, sebanyak 31 responden memiliki tingkat stress psikososial yang ringan, sebanyak 2 responden memiliki tingkat stress psikososial yang sedang dan tidak ada responden yang memiliki tingkat stress psikososial yang berat. Berdasarkan status gizi responden sebagian besar berada pada rentang gizi yang normal yaitu sebanyak 81 responden, sebanyak 8 responden berada pada status gizi risiko obesitas, sebanyak 2 responden 
berada pada status gizi obesitas dan terdapat 1 responden memiliki status gizi kurang. Hubungan antara stress psikososial dengan status gizi dapat dilihat pada tabel dibawah ini

Tabel 1. Hubungan stress psikososial dengan status gizi

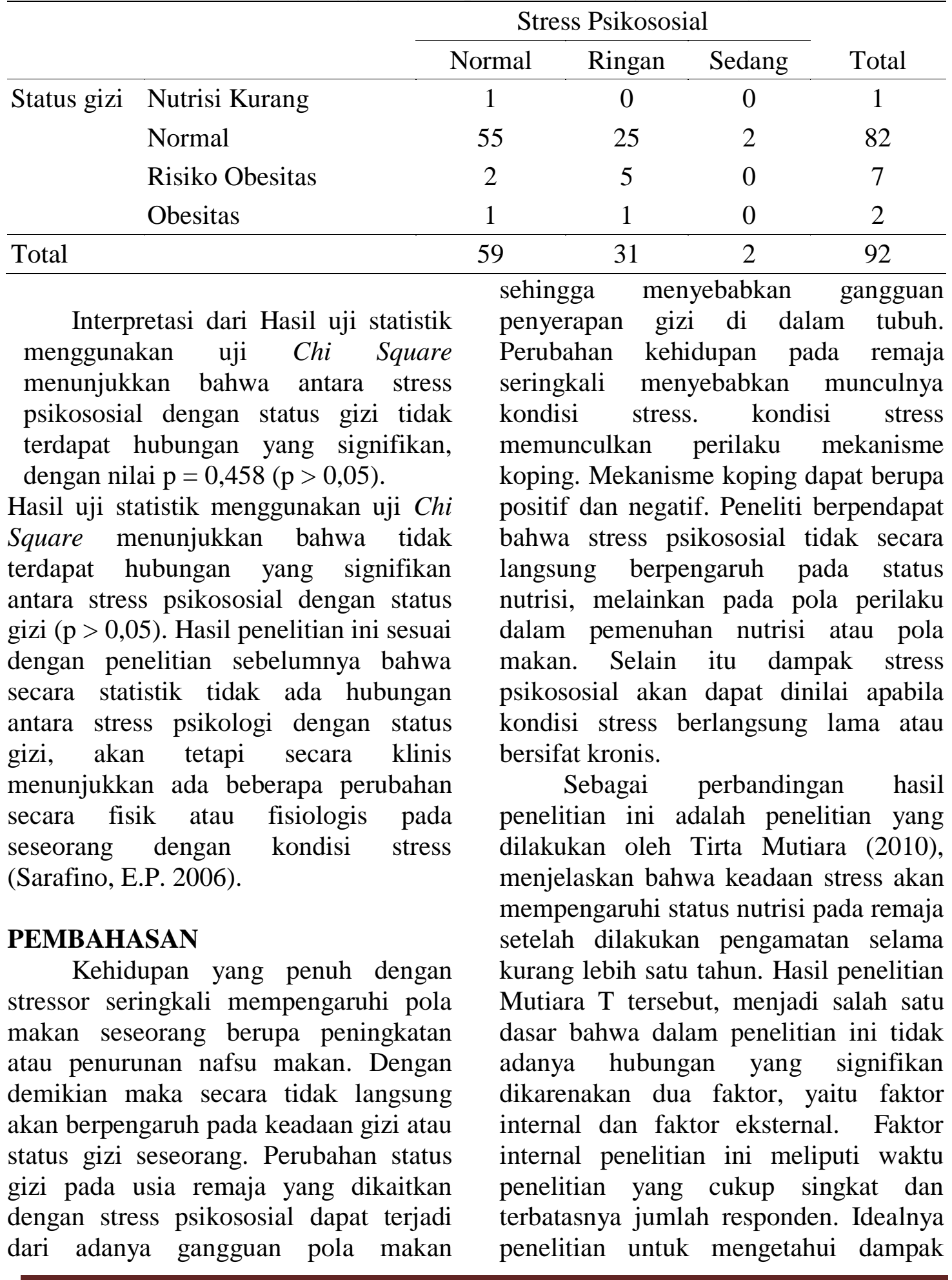


dari kondisi stress melalui pengamatan dalam waktu yang lama dengan menggunakan metode kohort, karena metode kohort adalah desain untuk menentukan kejadian dan proses pajanan terhadap efek terhadap subjek yang diteliti. Dari sudut pandang kondisi stress, tidak semua orang yang terpapar stressor akan mengalami stress, karena setiap orang mempunyai penilaian yang berbeda-beda terhadap stressor yang terjadi. munculnya dampak negative dari kondisi stress tergantung pada kepribadian individu, status kesehatan, persepsi tentang stressor, pengalaman individu, serta nilai-nilai spiritual.

Faktor eksternal dari tidak adanya pengaruh yang signifikan antara stress psikososial dengan status nutrisi diantaranya kurangnya peranan stress psikososial terhadap status nutrisi. Faktor eksternal lainnya adalah adanya variabel tidak langsung yang berpengaruh pada status nutrisi yaitu asupan makanan. Dampak stress psikososial mungkin tidak muncul pada individu tertentu, hal ini disebabkan karena sumber-sumber mekanisme koping terhadap stress yang dimiliki oleh seseorang, seperti adanya support system pada individu (Sarafino, E.P. 2006). Pada individu remaja, support system dapat berasal dari keluarga, teman atau lingkungan dimana remaja tersebut tinggal. Individu pada saat mengalami kondisi stres, perilaku makan akan mengalami perubahan dan sering mengakibatkan obesitas atau kelebihan berat badan. Stres psikologis seringkali dikaitkan dengan konsumsi makanan yang meningkat, terutama dalam mengkonsumsi makanan berlemak tinggi. Stres dapat meningkatkan berat badan karena meningkatkan kadar kortisol darah, mengaktifkan enzim penyimpanan lemak dan memberi tanda lapar ke otak.
Stres kronik pada individu tertentu dapat juga menekan nafsu makan. Keadaan depresi yang dapat dipicu oleh stres yang kronik berhubungan dengan penurunan nafsu makan. Terdapat 2 macam peruba han pola makan akibat stres. Ada individu yang pada keadaan stres lebih banyak mengkonsumsi makanan (emotional eaters) dan sebaliknya ada individu yang pada keadaan stres pola makannya tidak terpengaruh atau dikurangi (nonemotional eaters). Pada individu dengan emotional eater, saat stres kadar ghrelin yang meningkat dalam darah berubah dengan meningkat- kan makan. Sebaliknya, pada individu dengan non emotional eater kadar ghrelin dengan cepat kembali ke tingkat basal dengan makan. Oleh karena itu, se- orang dengan emotional eater relatif membutuhkan lebih banyak makan untuk menekan ghrelin diband- ingkan dengan seorang non emotional eater.

\section{KESIMPULAN}

Berdasarkan hasil penelitian ini, peneliti menyimpulkan bahwa sebagian besar responden memiliki status psikososial yang normal dan status gizi baik. Selain itu diketahui hubungan yang tidak signifikan antara stress psikososial dengan status gizi, namun secara klinis terdapat perubahan-perubahan fisiologis yang ditemukan pada responden dengan tingkat stress sedang.

\section{SARAN}

Saran yang dapat diberikan kepada peneliti selanjutnya adalah perlu diperhatikan waktu penelitian dan instrumen penelitian. dibutuhkan waktu yang lama dan jumlah sampel yang banyak untuk melakukan pengamatan serta menggunakan metode kohort, karena metode kohort adalah desain untuk menentukan kejadian dan proses 
pajanan terhadap efek terhadap subjek yang diteliti.

DAFTAR PUSTAKA

Andriani, M. dkk. 2012. Peranan gizi dalam siklus kehidupan. Jakarta: Prenada Media.

Brown, Judith E. et al. 2005. Nutrition Throught The Life cycle Second Edition. USA: Wadsworth.

Depkes RI. 2013. Laporan hasil riset kesehatan dasar (Riskesdas) Nasional. Badan Penelitian dan Pengembangan. Jakarta: Departemen Kesehatan RI.

http://www.depkes.go.id/article/view/1 8051600005/kenali-masalah-giziyang-ancam-remajaindonesia.html

Husnah. 2012. Gambaran pola makan dan statsu gizi mahasiswa kuliah klinik senior (KKS) di bagian obsgyn RSUD Dr. Zainoel Abidin Banda Aceh. Banda Aceh. Jurnal Kedokteran Syiah Kuala Vol. 12 No. 1 April 2012.
Kemenkes RI. 2013. Keputusan Menteri Kesehatan Republik Indonesia. No. 1995/MENKES/SK/XIV 2010 tentang standart antropometri penilaian status gizi. Jakarta : Departemen Kesehatan RI.

Santrock. 2003. Perkembangan Remaja. Edisi Keenam. Jakarta: Erlangga

Sarafino, E.P. (2006). Health Psychology : Biopsychosocial Interactions. Fifth Edition.USA : John Wiley \& Sons.

Sarwono. 2010. Psikologi Remaja. Edisi Revisi. Jakarta: Raja Grafindo Persada.

Sugiyono. 2010. Statistik untuk penelitian. Bandung: Alfabeta

Tirta Mutiara, Wirasto Ronny T, Huriyati Emy. (2010). Status stress psikososial dan hubungannya dengan status gizi siswa SMP Stella Duce 1 Yogyakarta. Jurnal Gizi Klinik Indonesia Vol. 6 No. 3, Maret 2010: 138-144. 